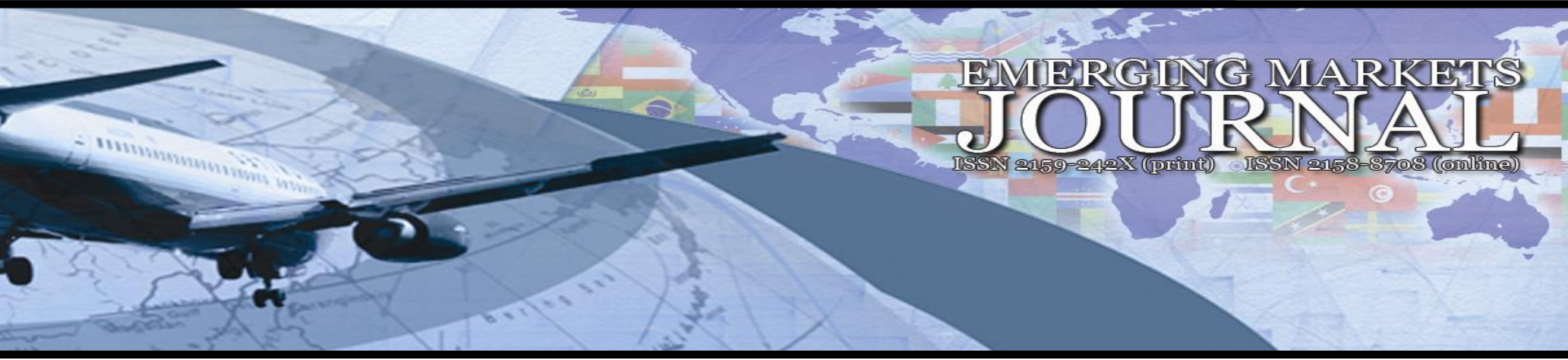

\title{
Problems of Accounting Professionals Residing in Istanbul and the Suggested Solutions
}

\section{Mustafa Uçar}

Biruni University, Turkey | mustafaucar@biruni.edu.tr

Cevdet Kızl

Istanbul Medeniyet University, Turkey | cevdet.kizil@ medeniyet.edu.tr

\section{Ŏguzhan Oğuz}

Kuveyt Türk Participation Bank, Turkey | oguzhanoguz22@ hotmail.com.tr

Volume 8 No 1 (2018) ｜ ISSN 2158-8708 (online) | DOI 10.5195/emaj.2018.150 | http://emaj.pitt.edu |

\begin{abstract}
Some problems of accounting professionals in Turkey were solved with the introduction of Law on Public Accountants, Certified Public Accountants and Sworn-in Certified Public Accountants in 1989. However, many other problems still remain to be solved for accountants in Turkey as of 2018. There were two main objectives of this study. The first one was to identify the problems faced by accounting professionals living in Istanbul, Turkey and the second one was to come up with solutions for these problems. The eesearch took advantage of questionnaire methodology. According to research findings, accounting occupation doesn't have a professional identity in Turkey. Also, accounting education given in universities is perceived as inadequate. The leading reason why accounting professionals are only considered as bookkeepers in Turkey is knowledge defficiencies. The main motivation behind choosing the accountant career path is commercial (monetary). The leading reason for lack of confidence against accountants in Turkey is ignorance of accounting ethics. Lack of practice is the leading deficiency concerning accounting education in Turkey. This is followed by insufficient accounting ethics education. Leading problems of accounting professionals in Turkish business life are economical. Our literature review shows that, expectations from public authorities, professional accounting chambers and bodies increase to solve the problems of accounting professionals. Thus, the suggested solutions by this study to eliminate determined problems of accounting professionals should be evaluated and considered by public authorities, professional accounting chambers and bodies. Moreover, effective communication, coordination and agreement on legal arrangements must be present among accounting professionals, chambers, bodies and public authorities to solve the problems of accounting professionals residing in Istanbul, Turkey.
\end{abstract}

Keywords: Accounting, Accounting Professionals, Problems, Solutions, Istanbul

\section{$(\mathrm{cc}) \mathrm{EY}$}

New articles in this journal are licensed under a Creative Commons Attribution 3.0 United States License.

\section{UILIS D-Surte}

This journal is published by the University Library System of the University of Pittsburgh as part of its D-Scribe Digital Publishing Program, and is cosponsored by the University of Pittsburgh Press. 


\section{Problems of Accounting Professionals Residing in Istanbul and the Suggested Solutions}

\section{Mustafa Uçar \\ Cevdet Kızıl \\ Ŏguzhan Oğuz}

\section{Introduction}

The efficient operation and development of businesses that form the basis of economies depend on a well-functioning accounting and control system. There is no doubt that, inefficient accounting and control systems, particularly weak internal controls cause creative accounting practices, manipulation of financial data, fraud and risk (Kızıl, Şeker, Akman, Işık, Demirkol and Kefeli, 2015; Kız1l, Çelik, Akman and Şener, 2016; Aslan, Kızıl and Din, 2017; Adalı and Kızıl, 2017). Parallel to this issue, healthy functioning of the economic and financial structure depends on accounting professionals at macro level. Also, accounting is called and known as the heart of business management in micro level (Kızıl, Çelik, Akman and Danışman, 2015). For this reason, accounting profession is among the most important occupational groups from the perspective of business world and government (Terzi, 2015).

Along with changes in the economy, in addition to financial reporting, the audit function has also brought important responsibilities to the members of accounting profession. As a result of these responsibilities, there are some contradictions and disputes in the value proposition of accounting profession, rules and decisions, as well as perceived problems. Members of accounting profession have to continue their activities while adhering to accounting ethics, despite the problems they experience (Deran, Erduru and Keleş, 2016). Although, the consciousness towards accounting ethics has improved tremendously in the recent years among accounting professionals, specific problems and missing points still exist (Kız1l, Akman, Aras and Erzin, 2015)

Today, in order to understand the development of accounting profession, it is necessary to examine the historical development of accounting. If the difficulties faced by the profession in this process and the issues affecting the profession are examined in relation to today's conditions, the future of accountancy can be shed light on. Developments such as globalization, new economic conception, political expansions, external and internal conjuncture have determined and also shaped the route of accounting profession. The accounting profession in Turkey experienced a regulation and arrangement with the law numbered 3568 in the 1989. Until this date, various foundations and associations had been involved in accounting activities and had prepared the infrastructure of an occupational law in order to give the accounting profession a legal status. With the acceptance of the law numbered 3568, the accounting profession began to earn its deserved reputation in Turkey (Kaya, 2015). But, it is still questionable if the accounting profession completely achieved to earn its desired reputation, image and identity in Turkey (K1zıl, Akman, Zorkalkan, Türkmen, 2015).

Accounting professionals have a number of responsibilities towards the government, their clients, colleagues and even themselves. Accounting professionals working with the consciousness of these responsibilities are trying to produce and present information that is understandable, accurate and reliable. While carrying out all these activities, accounting professionals encounter various problems in their lives and expect these issues to be solved (Tükenmez and Kutay, 2005).

\section{Literature Review}

In the recent years, there has been a significant increase in the number of research conducted on the problems of accounting professionals. For example, Uzay and Gungor (2004) pointed out that the problems of accounting professionals in their jobs. This study revealed that, the taxpayers cannot keep track of the amendments that are frequently made in the legislation. 
Clients' inability to pay accounting fees on time, excessive workload of accounting professionals and unfair competition among accountants were other determined problems.

The study conducted by Kalaycı and Tekşen (2006) expressed clients' pressure over members of the accouting profession in the direction of low tax calculation. Regular changes in the legislation and arrangements, unfair competition among accounting professionals, excessive workload of accountants and clients' not paying accounting fees on time were also other mentioned problems.

The aim of Usul and Aslantaş's (2007) study was to reveal the causes of conflict between accounting professionals and clients. The viewpoints of clients and accounting professionals were also presented in this research. According to the study, it was determined that conflicts between accounting professionals providing service and the clients requesting service from accountants existed. The conflicts were mainly as a result of viewpoint of clients towards accounting professionals.

Another research was carried out by Özulucan, Bengü and Özdemir (2010). This study assessed the problems of accounting professionals under three titles (topics). These were the problems faced in practice, the problems experienced through the application of legislations and the problems related to accounting chambers.

The motivation of Karcioğlu and Yazarkan's (2011) study was to determine the problems faced by accounting professionals residing in the provincial centers of İzmir and Erzurum during their activities related to public institutions. According to the results of research, it was determined that accounting professionals had problems such as lack of knowledge, bureaucratic issues and legal arrangements.

Y1ldırım and Güney (2012) attempted to emphasize some of the problems of accountanting professionals. In the study, it was determined that the members of accounting profession were faced with job burden and difficulties much more than the advantages and benefits of their occupation. Also, the frequent law and arrangement changes were impairing the relationship between clients and accounting professionals.

Tuğay and Tekşen (2014) conducted a research investigating the problems of accounting professionals. This study argued that, the best accountant was perceived by the society as the one enabling and helping clients to pay least tax. Additional problems of accounting professionals were underlined by the research such as frequent changes in laws and regulations which were not followed in a timely manner, accounting colleagues keeping books under the base salary determined by accounting chambers, the occupational (job) burden brought by the profession which is excessive and the clients not pay their fees to accountants on time.

\section{Society's Expectations from Accounting Professionals}

There are several stakeholders, who benefit from the information generated, produced and presented by accounting professionals. The timely delivery of accurate and reliable information is a major expectation of all stakeholders. The most evident expectation of investors and shareholders from accounting professionals in the recent years is especially transparency (Kızıl, Fidan, Kızıl and Keskin, 2013; Kızıl, Fidan, Kızıl and Keskin, 2016; Tayyar, 2001). That is definitely a critical concept also in terms of mergers, acquisitions and investments. Stakeholders of today's business world such as investors, shareholders, entrepreneurs, auditors and government are in need of more standardized global accounting principles (Kızıl, Çetin and Bulunmaz, 2014).

In addition, the business community wants financial statements to be understandable, flexible and focused on needs. The accountant should present the information on the basis of materiality and priority. It should be noted that, a serious amount of information can be misleading and inaccuarate. Providing and presenting less information compated to the required level should be evaluated in the same context. In order for financial statements to be more meaningful, accounting for inflation implementations is now also expected from accounting professionals (Suadiye and Yükselen, 2001). 
Accounting professionals want their clients to provide them timely and sufficient information, and to ensure that accounting service fees are paid on time. On the other hand, quality service demand by the business world is also important for the improvement of services offered by accountants. The main expectation of firms from accounting professionals is that, the accounting records are kept reliable and impartial in order to obtain the exact results (Taner, Korukoğlu Dalgeç and Susmuş, 2001).

Moreover, Certified Public Accountants (CPAs) and Sworn-in Certified Public Accountants do tax auditing by signing tax declarations and effectively implementing controls. In addition, accounting professionals are a source of tax revenue generations. Without accounting and accountants, there would actually be no tax collection. Thus, the governments always expect accounting professionals to carry out an effective, fair and responsible role in tax collection (Seviğ, 2002).

Plus, the main responsibility of accounting professionals is to serve the society and protect its interests. For this reason, business ethics, accounting ethics and value judgments have become more prominent in recent years, as well as professional knowledge. Acquiring moral and ethical values related to the occupation will also increase the value of the accounting profession in society. Thus, one of the leading expectations of society from accountants today is adherence to ethical values (Selimoğlu, 2001).

In order for the accounting profession to be recognized at a desired level in society, it is necessary for the government, professional accounting organizations, chambers and bodies to work together continuously. Turkey still does not make full use of knowledge of accounting professionals (Güvemli, 2001).

\section{Data and Methodology}

The target population of the study is accounting professionals residing in the city of Istanbul, Turkey. For this purpose, the sample of the study is selected from 35 accounting professionals. Questionnaires were distributed to 35 accounting professionals, who are registered members of the Istanbul Chamber of Certified Public Accountants and Chamber of Sworn-in Certified Public Accountants of Istanbul. They consist of 30 Certified Public Accountants (CPAs) and 5 Sworn-in Certified Public Accountants. The questionnaire used for this research included general items, demographical information, majors, perceptions, thoughts and problems about accounting professionals as well as items on accounting education, accounting ethics and accounting career path.

\section{Research Findings}

Questionnaire distributed to accounting professionals residing in Istanbul firstly presented demographic information about the mentioned accountants. $71,4 \%$ of accounting professionals participating in the research were male. $28,6 \%$ of accountants taking the survey were female.

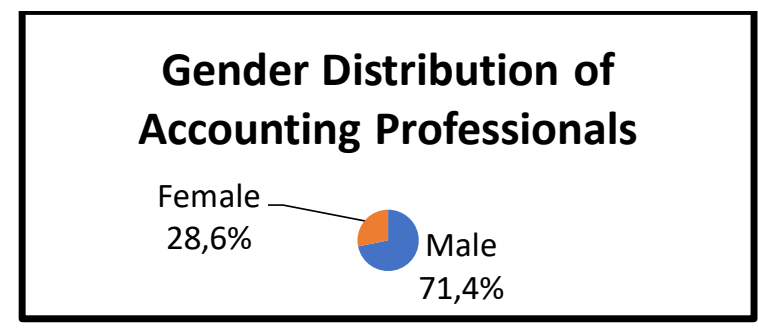

\section{Figure 1. Gender Distribution of Accounting} Professionals

Based on research findings, accounting professionals taking the questionnaire were mostly management and finance majors. 51,4\% of accounting professionals had management and finance educations (diplomas). In other words, 51,4\% of accounting professionals had management and finance degrees. $48,6 \%$ of accounting professionals had graduated from other departments. 


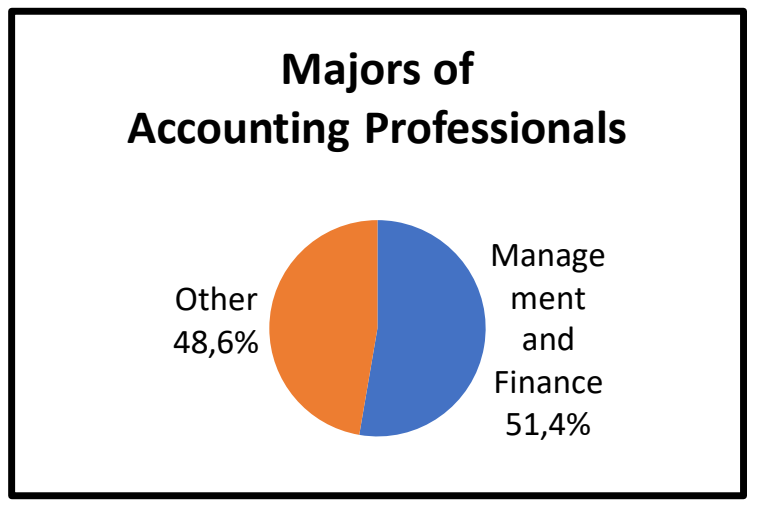

Figure 2. Majors of Accounting Professionals

The questionnaire utilized by study also included a statement, which mentioned that accounting occupation now had a professional identity in Turkey. Reseach findings indicate that, this statement is not accepted by most of accounting professionals residing in Istanbul, Turkey. 68,5\% disagreed with this statement while the agreement ratio was $31,5 \%$.

\begin{tabular}{|c|}
\hline Accounting Occupation \\
now has a Professional \\
Identity in Turkey \\
No \\
$31,5 \%$ \\
Yes \\
$68,5 \%$ \\
\hline
\end{tabular}

Figure 3. Accounting Occupation now has a Professional Identity in Turkey

Also, according to research findings, $80 \%$ of accounting professionals think that the accounting education given in universities is inadequate. On the other hand, $20 \%$ of accounting professionals believe that the accounting education given in universities is adequate. Thus, research findings signal a problem concerning accounting education in Turkish universities.

\section{Accounting Education given in Universities}

Adequ

ate

$20 \%$ Inadequ ate $80 \%$

Figure 4. Accounting Education given in Universities

Today's business world has assigned several critical roles to accounting professionals. Interpretation and analysis of financial statements, expertise in analytical thinking and auditing are only some of these critical roles. However, clients in Turkey still mainly consider accounting professionals as only bookkeepers.

The research also investigated the leading reason why accounting professionals were only considered as bookkeepers in Turkey. Parallel to research findings, the leading reason was the knowledge deficiencies of accounting professionals while they were interacting with clients. 54,2\% of accounting professionals stated in the questionnaire that, accountants in Turkey were only perceived as bookkeepers because of their knowledge deficiencies. 45,8\% of accounting professionals disagreed at this point that the leading reason was knowledge deficiencies and they reported that other reasons were effective.

\section{The Leading Reason why Accounting Professionals are only considered as Bookkeepers in Turkey}

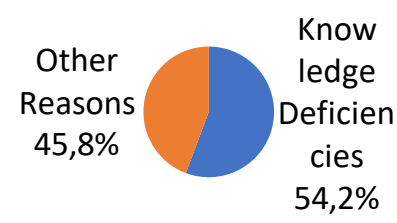

Figure 5. The Leading Reason why Accounting Professionals are only considered as Bookkeepers in Turkey 
The research findings revealed that, $57,1 \%$ of accounting professionals chose this career path because of commercial (monetary) motivation. In other words, the accounting profession in Turkey is mostly run with commercial (monetary) concerns. Although main motivation behind choosing the accountant career path is commercial (monetary) with a ratio of $57,1 \%$, other motives do exist which are equivalent to $42,9 \%$.

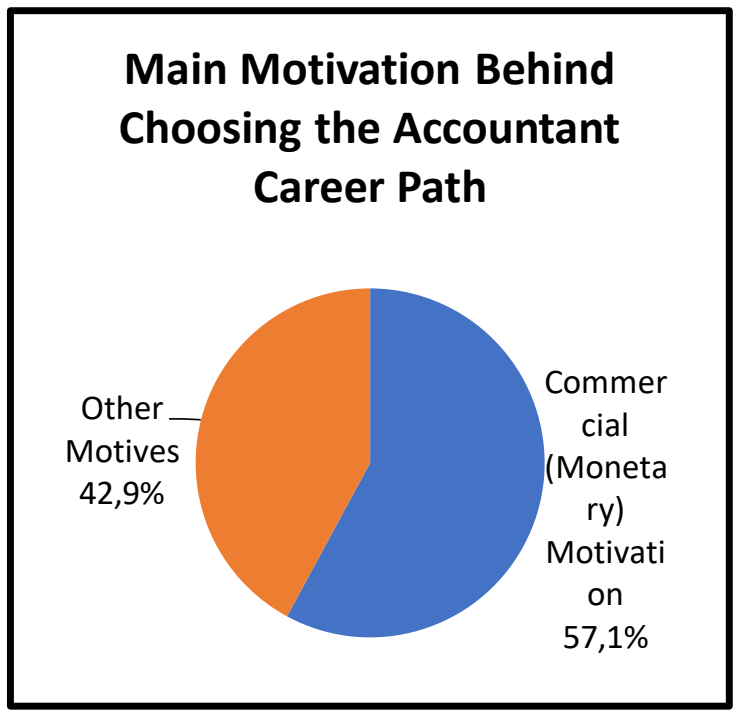

Figure 6. Main Motivation Behind Choosing the Accountant Career Path

The study also investigated the reason for lack of confidence against accountants in Turkey. 62,8\% of respondents stated that, the leading reason for lack of confidence against accountants in Turkey was ignorance of accounting ethics. $37,2 \%$ of respondents said other reasons did exist.

\section{The Reason for Lack of Confidence against Accountants in Turkey}

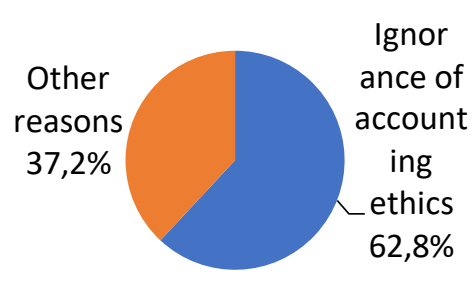

Figure 7. The Reason for Lack of Confidence against Accountants in Turkey
Then, the research examined the leading deficiencies concerning accounting education in Turkey. $60 \%$ of accounting professionals as the respondents of research said lack of practice was the leading deficiency concerning accounting education in Turkey. This was followed by insufficient accounting ethics education with $25,7 \%$. However, $14,3 \%$ of respondents stated that other deficiencies were present. So, accounting professionals generally believe that practial accounting knowledge is very significant in today's business world. They also think that, junior accountants at the beginning of their careers experience big difficulties in transforming their theoretical knowledge into practice.

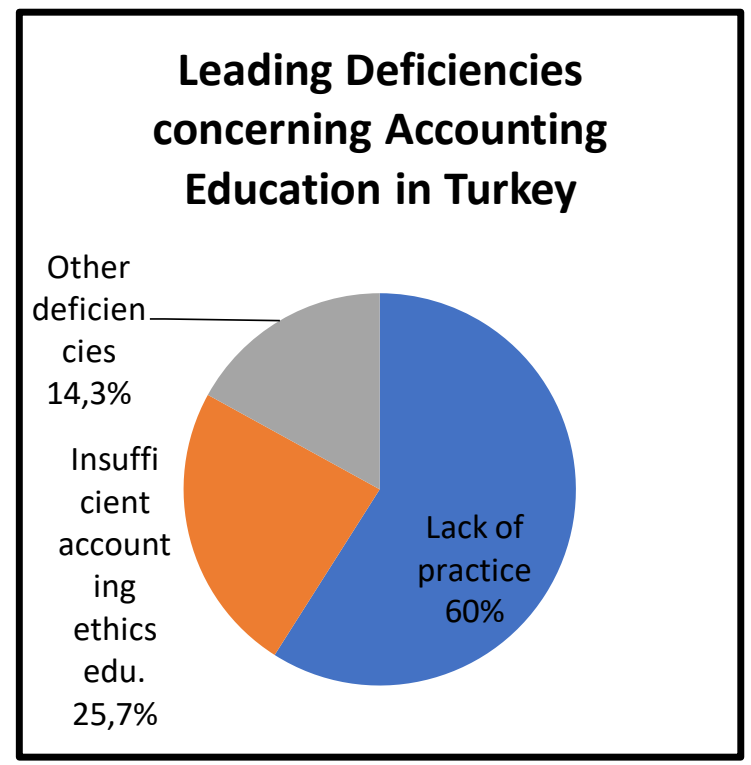

Figure 8. Leading Deficiencies concerning Accounting Education in Turkey

Questionnaire utilized by the research also asked accounting professionals their leading problems in Turkish business life. Economical problems of accountants are taking the lead for this statement with $51,4 \%$. In this regard, accounting professionals stated that they were experiencing great difficulties in fee (rate) collections from their clients. Especially, it was emphasized that, no fee (rate) collections were possible especially during economical crisis periods. Still, $48,6 \%$ of respondents believed that accounting professionals had other leading problems in Turkish business life. 


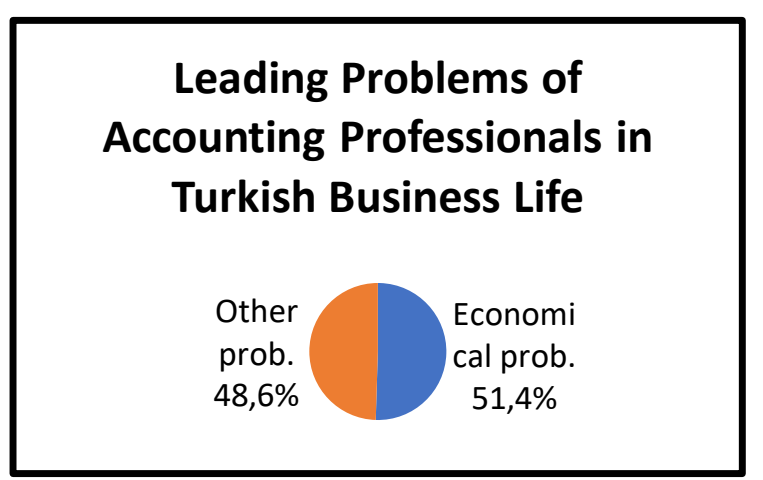

Figure 9. Leading Problems of Accounting Professionals in Turkish Business Life

\section{Conslusion and Recommendations}

Accountants assist businesses through their financial decision-making process, and also build their communication bridge with various stakeholders. As one of the most important actors in modern economy, both the duties and responsibilities carried by accounting professionals have increased. That has caused accounting professionals to face various problems while sustaining their daily activities.

Although the Law on Public Accountants, Certified Public Accountants and Sworn-in Certified Public Accountants was enacted in 1989 in order to solve the problems of Turkish accounting professionals and to bring a legal basis to accounting profession, it was never enough to eliminate all problems. Parallel to the developments in business life, problems of accounting professionals have gained different dimensions. This research aimed to analyze the problems of Turkish accounting professionals and offer possible solutions.

The research presented some important findings related to the problems of accounting professionals residing in Istanbul, Turkey. First, based on research findings, accounting occupation still doesn't have a professional identity in Turkey. Some solutions to this problem are possible. For example, laws and regulations related to accounting should be continuously updated in Turkey to satisfy contemporary needs of all stakeholders. Accounting chambers, bodies and the government should be more selective when accepting new Certified Public Accountants (CPAs) and Sworn-in Certified Public Accountants to the profession. In this context, the difficulty level of accounting exams can be highered. Also, any new canditate for accounting profession with unethical records and history must be denied. Similarly, present and existing accounting professionals committing unethical behavior should have their accounting licences terminated or they must face serious financial penalties. Additionally, base fees of accounting professionals which they collect from clients must be higher.

Second, a high majority of accounting professionals think that the accounting education given in universities is inadequate. Adopting a new approach to planning accounting education in universities and giving more emphasis to implementation/practice can be considered an important step for the solution of this problem. For a more effective solution, higher number of accounting elective courses may be offered to students who wish to become members of accounting profession. These students should also be supported by universities, faculty members and the government to have internship in accounting offices. Also, more practical knowledge should be integrated in delivered accounting courses besides the theoretical knowledge. Definitely, technology should be utilized much more through the semester. Lecturing the course with powerpoint slides, using interative videos and introducing accounting programs (software) are all critical at this point, in addition to traditional accounting education. Furthermore, accounting courses should also include case studies, reading materials, teamwork (group work) and brainstorming. Plus, active learning must be adopted by giving assignments to students instead of insisting on passive learning. Moreover, universities can also consider employing faculty members who hold the Ph.D. and CPA/Sworn-in Public Accountant titles together.

Third, the leading reason why accounting professionals were only considered as bookkeepers in Turkey was the knowledge deficiencies of accounting professionals while they were interacting with clients. 
We believe that, the constant changes in laws and regulations are making the job of accounting professionals harder at this point. This increases the responsibilities and job burden of accountants in Turkey.

As a result, knowledge deficiencies of accounting professionals are observed. In order to solve this problem, Turkish accountants should improve themselves continuously and they must read the latest updates concerning laws and regulations daily. In other words, accounting professionals should definitely acquire reading habit. This is especially critical and important for following changes and updates in tax legislation. Accounting chambers, bodies and the government should also support accounting professionals by organizing seminars, workshops, conferences and congresses which require no rates or low registration fees. In fact, accounting chambers, bodies and the government must always be active to solve the various problems of accounting professionals in Turkey.

Fourth, the research findings revealed that, most accounting professionals chose accounting career path because of commercial (monetary) motivation. In other words, the accounting profession in Turkey is mostly run with commercial (monetary) concerns. This finding is important in the sense of accounting ethics. In other words, that situation brings negative consequences in terms of accounting ethics. In order to keep accounting professionals away from solely commercial concerns, accounting chambers should focus on and communicate the contribution of accounting science for public welfare. The benefits and advantages of accounting for public must be underlined. Also, accounting professionals should be motivated to see the big picture and understand the positive outcomes of their job performance. Definitely, it must be ensured that the base rate (fee) application is followed very seriously by accountants. In this respect, accounting professionals should not try to keep books lower than standard fees (rates) determined by accounting chambers and bodies. Such an action against laws and regulations solely based on unfair commerial (monetary) gains must be penalized. Government, accounting chambers and bodies should give high penalties to accounting professionals ignoring accounting ethics. Termination of Certified Public Accountant (CPA) and Sworn-in Certified Public Accountant licences should also be discussed at this point.

Fifth, the study also investigated the reason for lack of confidence against accountants in Turkey. Most respondents stated that, the leading reason for lack of confidence against accountants in Turkey was ignorance of accounting ethics. Offering mandatory accounting ethics courses in universities besides elective ones can be a solution for this problem. Also, the government, accounting chambers and bodies should organize conferences, congresses, seminars and workshops on accounting ethics frequently. Moreover, accounting professionals adhering to accounting ethics can be awarded by the government, accounting chambers and bodies. Financial penalties and termination of accounting licenses can also be matters of solutions for the mentioned problem of unethical behavior.

Sixth, the research examined leading deficiencies concerning accounting education in Turkey. Most accounting professionals as the respondents of research said lack of practice was the leading deficiency concerning accounting education in Turkey. This was followed by insufficient accounting ethics education. A variety of solutions can be thought to solve these problems. One of them is integrating technology to accounting courses. Modern accounting education methods should be implemented instead of traditional accounting education techniques. Also, students should be made familiar with using accounting programs (software). Through the semester accounting videos, case studies, reading materials, presentations, assignments, team work (group work), discussions and brainstorming should be utilized frequently. Universities must also encourage and support students for accounting internships. Absolutely, it would be better for faculties to employ academicians who hold both the Ph.D. and Certified Public Accountant (CPA)/Sworn-in Certified Public Accountant titles simultaneously. For sure, more business ethics and accounting ethics courses should be offered by universities as mandatory courses, not only as 
selective courses. This is of course only possible with broadening the number of accounting lecturers in faculties, which is a must for Turkish universities.

Seventh, according to research findings, the leading problems of accounting professionals are economical. In this regard, most accounting professionals stated that they were experiencing great difficulties in fee 8rate) collections from their clients. Especially, it was emphasized that, no fee (rate) collections were possible particularly during economical crisis periods. Specific solutions are possible for this problem. For instance, insurance systems which guarantee the fee (rate) collections of accounting professionals can be activated and initiated. Also, firms not paying their fees (rates) to accountants in Turkey can be included in a blacklist, which would be accessible to accounting professionals, chambers, bodies and the government. Serious financial penalties must apply for businesses not paying their fees (rates) to accountants. It is evident that, a high number of accounting professionals are keeping books under the required base rate causing unfair competition, and these low rates (fees) are still not sometimes paid. Even if rates (fees) are collected, there are delays in payments. These problems of accounting professionals still wait to be solved as burning issues for several years, which are damaging the reputation of accounting in Turkey.

\section{References}

Adal1, S. and Kizıl, C, (2017), A Research on the Responbility of Accounting Professionals to Determine and Prevent Accounting Errors and Frauds: Edirne Sample, Emerging Markets Journal (EMAJ), Vol. 7, No: 1, 53-64.

Aslan, T., Kızıl, C. and Din, A, (2017), Muhasebe Hata ve Hileleri Üzerinde Etkili Faktörlerin Muhasebe Meslek Etiği Kapsamında Analizi: Yalova Örneği, Journal of Social and Humanities Sciences Research, Vol:4, Issue:5, 1125-1138.
Deran, A., İncilay E. and Keleş, D, (2016), Muhasebe Meslek Mensuplarının Mesleki Sorunları ve Meslek Odalarından Beklentilerinin Demografik Özellikler Ve Faaliyet Gösterilen Ekonomik Çevre Açısından Değerlendirilmesi: Ordu Örneği, Selçuk Üniversitesi İktisadi ve İdari Bilimler Fakültesi Sosyal Ekonomik Araştırmalar Dergisi (The Journal of Social Economic Research) ISSN: 2148 - 3043 / Ekim 2016 / Y11: 16 / Say1: 32.

Güvemli, O, (2001), 3568 Sayılı Serbest Muhasebecilik, Serbest Muhasebeci Mali Müşavirlik ve Yeminli Mali Müşavirlik Kanunu'nda Değişiklik Teklifi Üzerine, MUFAD, Sayı:10, 33-36.

Kalayc1, Ş. And Tekşen Ö, (2006), Muhasebe Mesleğinde Karşılaşılan Sorunlar ve Çözüm Önerileri: Isparta İl Merkezi Uygulamas1, Muhasebe ve Finansman Dergisi, Say1: 31, 90101.

Karcioğlu, R. and Yazarkan H, (2011), Muhasebe Meslek Mensuplarının Faaliyetleri Sırasında Kamu Kurumlarında Karșılaștıkları Sorunlara İlişkin Ampirik Bir Araştırma, Muhasebe ve Denetime Bakış Dergisi, Sayı: 34, 1-12.

Kaya, G. A., (2015), Muhasebe Meslek Mensuplarının Sorunları ve Çözüm Önerileri: Elazığ'da Bir Araştırma, International Journal of Social Science, Doi number: http://dx.doi.org/10.9761/JASSS3089, Number: 41 , p. 207-231, Winter II, 2015.

Kızıl, A., Fidan M., Kızıl, C. and Keskin, İ., (2013), TMS-TFRS Türkiye Muhasebe ve Finansal Raporlama Standartları, İstanbul: DER Yayınları.

Kızıl, A., Fidan, M., Kızıl, C., and Keskin, İ., (2016), TMS-TFRS Turkiye Muhasebe ve Finansal Raporlama Standartları, Uygulamlar-YorumlarMuhasebeleştirme (2. Basım). İstanbul: Der Yayınları. 
Kızıl, C., Akman, V., Aras, S. and Erzin, N. O, (2015), Yalova İlinde İkamet Eden Muhasebe Meslek Mensuplarının Muhasebe Etik Alg1s1, Beykent Üniversitesi Sosyal Bilimler Dergisi, 8(1), 631.

Kızıl, C., Akman, V., Zorkalkan, T., Türkmen, R, (2015), Muhasebenin Tarihine Küresel Kapsamda ve Türkiye Kapsamında Vergisel Bir Bakış, Leges Sosyal Bilimler Dergisi, 15 Eylül 2014-15 Ocak 2015, Y11: 5, Sayı: 3, 70-87.

Kızıl C, Çelik İ. E, Akman V, Danışman D, (2015), Muhasebe dersini ilk kez alan öğrencilerin başarısına etki eden faktörlerin tespiti: Yalova üniversitesinde bir uygulama. İşletme Bilimi Dergisi 3(2): 127-165.

Kızıl, C., Çelik, İ. E., Akman, V. and Şener, S. (2016). Yaratıcı Muhasebe Yöntemleri Ve Finansal Bilgilerin Manipülasyonu: Profesyonel Muhasebe Meslek Mensupları Üzerinde Örnek Bir Uygulama, Beykent Üniversitesi Sosyal Bilimler Dergisi, 9(1), 1- 18.

Kızıl, C., Çetin, A. T., and Bulunmaz, A, (2014), Accounting Education Approach in the Context of New Turkish Commercial Code and Turkish Accounting Standards. Emerging Markets Journal, 4(1), 72.

Kızıl, C., Şeker, Ş.E., Akman, V., Işık, E. Y., Demirkol, V., Kefeli, S, (2015), Muhasebe Finansman, Yönetim Organizasyon ve Yönetim Bilişim Sistemleri Yazıları, Leges Yayınları.

Özulucan, A., Bengü H. and Özdemir, F. S., (2010), Muhasebe Meslek Mensuplarının Güncel Sorunları, Uygulamada Karşılaştıkları Yetersizlikler ve Meslek Odalarından Beklentilerinin Unvanları ve Mesleki Deneyim Süreleri Yönüyle İncelenmesi: Türkiye Genelinde Bir Araştırma, Muhasebe ve Denetime Bakış Dergisi, Sayı: 31, 41-64.
Selimoğlu, S. K., (2001), Muhasebe Eğitiminin Meslek Mensubu Adaylarına Ahlaki Doğruları Kazandırmadaki Rolü, XX. Türkiye Muhasebe Eğitimi Sempozyumu, Ankara Üniversitesi S.B.F., 23-27, 3-27.

Seviğ, V., (2002), Muhasebe ve Mesleğin Önemi, Dünya Gazetesi, 26.09.2002.

Suadiye, G. ve Yükselen C., (2001), Mükelleflerin ve Muhasebecilerin Birbirlerinden Beklentileri, Mali Çözüm, İSMMMO Yayını, Sayı: 56, 5-26.

Taner, B., Korukoğlu Dalgeç A. and Susmuş T., (2001), Muhasebe Mesleğinin Müşterileri Durumunda Bulunan Kesimlerin Muhasebe Mesleğinden Beklentileri: İzmir İli Uygulaması, V. Türkiye Muhasebe Denetimi Sempozyumu, Yirmi birinci Yüzyllda Türk Muhasebe Mesleğinin Vizyonu ve Misyonu, İSMMMO Yayınları No:32, İstanbul, 169-182.

Tayyar, A., (2001), Türk İş Dünyasında Muhasebe Mesleğinden Beklenenler, V. Türkiye Muhasebe Denetimi Sempozyumu, Yirmi Birinci Yüzyılda Türk Muhasebe Mesleğinin Vizyonu ve Misyonu, İSMMMO Yayınları, 32, İstanbul, 163-168.

Terzi, A., (2015), Muhasebe Meslek Mensuplarının Meslekleri İle İlgili Beklentilerine, Sorunlarına ve Algılarına Yönelik Bir Araştırma: Rize Örneği, Ardahan Üniversitesi İktisadi ve İdari Bilimler Fakültesi Dergisi, Sayı: 2, Ekim 2015, 193-212.

Tuğay, O. ve Tekşen, Ö, (2014), Muhasebe Meslek Mensuplarının Sorunları: Burdur İlinde Bir Araştırma, Süleyman Demirel Üniversitesi İ̈B Dergisi, 19(1), 223-232.

Tükenmez, M. N. and Kutay N, (2005), Muhasebe Meslek Mensubunun Karar Alma Sürecinde Meslek Ahlakının Yeri: Çok Boyutlu Analiz İzmir Örneği, Muhasebe ve Finansman Dergisi, Sayı 25, İstanbul, 155-164. 
Usul, H. and Aslantaş, B.A, (2007), MuhasebeciMükellef Çatışması, Muhasebe ve Denetime Bakış Dergisi, Sayı: 22, 85-103.

Uzay, Ş. And Güngör Ş, (2004), Muhasebecilerin Sorunları ve Beklentileri: Kayseri ve Nevşehir İlleri Uygulaması, Muhasebe ve Finansman Dergisi, Say1:22, 94-104.

Yıldırım, S. and Güney S, (2012), Serbest Muhasebeci Mali Müşavirlerin Genel Sorunları: Erzurum İli Örneği, Muhasebe ve Denetime Bakış Dergisi, Say1: 36, 35-48. 